\title{
高温熱量計による鉄合金の混合熱の測定
}

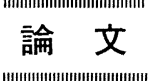

$-\mathrm{Fe}-\mathrm{Cr}, \mathrm{Fe}-\mathrm{Mo}, \mathrm{Fe}-\mathrm{W}, \mathrm{Fe}-\mathrm{V}, \mathrm{Fe}-\mathrm{Nb}, \mathrm{Fe}^{-} \mathrm{Ta}$

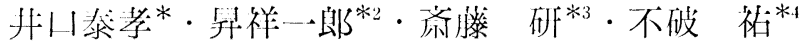

\section{A Calorimetric Study of Heats of Mixing of Liquid Iron Alloys $-\mathrm{Fe}-\mathrm{Cr}, \mathrm{Fe}-\mathrm{Mo}, \mathrm{Fe}-\mathrm{W}, \mathrm{Fe}-\mathrm{V}, \mathrm{Fe}-\mathrm{Nb}, \mathrm{Fe}-\mathrm{Ta}-$}

Yasutaka IGUciII, Shoichiro Nobori, Ken SAITo, and Tasuku FuwA

\begin{abstract}
Synopsis :
Heats of mixing of liquid iron with a few metals, having higher melting point than iron (i. e., chromium, molybdenum, tungsten, vanadium, niobium or tantalum), were measured at $1600^{\circ} \mathrm{C}$ by the developed isoperibol calorimeter. The method for measuring the heat of mixing of a liquid metal and another solid metal was checked by comparing the heat of mixing of liquid nickel and solid iron with that of liquid nickel and liquid iron.

The experimental errors were estimated to be less than $\pm 15 \%$ for the cases that a liquid metal was mixed with another solid metal.

Heats of mixing of binary iron alloys, for which the both reference states were liquid, were calculated by combining the present experimental results with the previously reported thermochemical properties. Mixing of liquid iron with liquid chromium, molybdenum, vanadium, niobium or tantalum was an exothermic reaction, while mixing of liquid iron-tungsten was endothermic.
\end{abstract}

\section{1. 緒言}

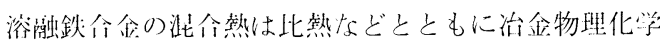
上重要な数值であるにもかかわらず，いまだ信頼去の高 い測定倠が少ないのが现状である。著者らは先に等温隹

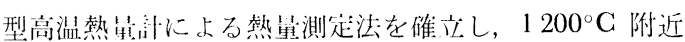
にて鈳全金 ${ }^{1)} 1450^{\circ} \sim 1550^{\circ} \mathrm{C}$ 附近にて二ッケル介金， コバルト介金2 そして $1600^{\circ} \mathrm{C}$ 附近の製鋼温度において 数種の鉄合金 ${ }^{3)}$ の混含熱を測定し報告して米た．本研究 では鋼の今金元素として垂要であるVa，VIa 族の金属， クロム，モリブデン，タングステン， バナジウム，二オ

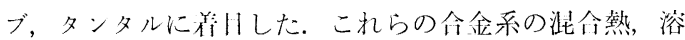
解熱は電父灿などによる合金鋼溶製に打ける合理的操業 法の解析などにも必要であるが，現在全く実測されてい ないと言つても過富でない。これらの金属は鉄より融点 がはるかに高い, したがつて本研究では，ニッケルー鉄 2 元系について|婟-液拈よび液一液混合による混合熱測定

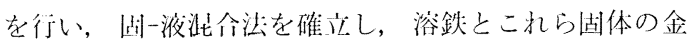

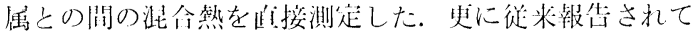
いるこれら純金風の熱化学データを用い液-液混合熱を 求めた。

\section{2. 実験装置および方法}

\section{$2 \cdot 1$ 実験装置}

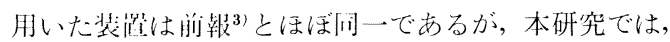
田一液混合であるため若トの收发を行つた。熱量計の断 面図を Fig. 1 に示寸。混合容器の材質は従来と同様へ リリアである。ベリリアは前㪕で用いた金属と同様本研 究に使用した試料金属とも核とんど反応せず，2３回綵 り返し使用が可能である。本研究では固-液混合であり 融点の低い鉄を常にストッハーを有する上部容器に装入 する。したがつて本測定法の原理である熱移動条件を満 足するために必要な試料体積 (下部容器の 8 割以上) ${ }^{1)}$ なわち重量で鉄 $1 / 2 \mathrm{~g} \cdot$ atom, 合金量として約 $30 \mathrm{~g}$ 以上 装入できるFig. 1 で示す内容積の大きな容器を製作し 使用した。この絬果，阅報までに詳細に述べられている

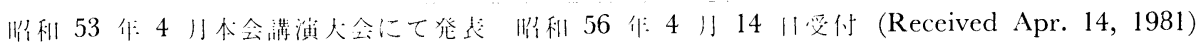

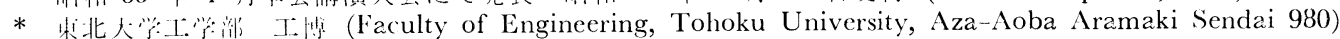

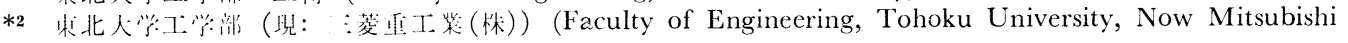
Heavy Industries, Ltd.)

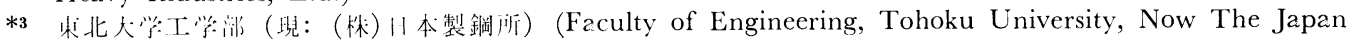
Steel Works, Ltd.)

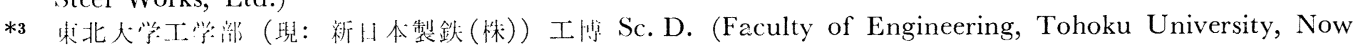
Nippon Steel Corp.) 


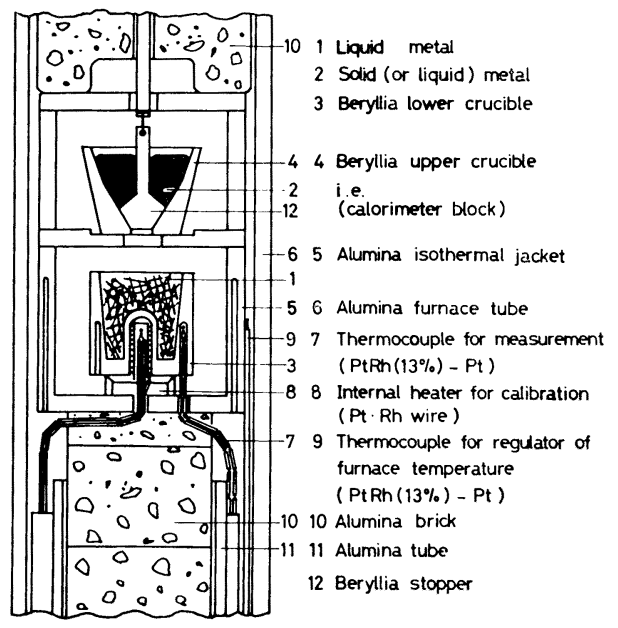

Fig. 1. Calorimeter assembly.

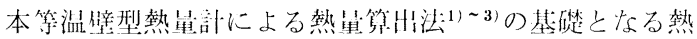

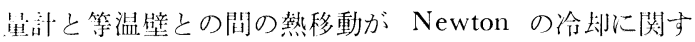
る近似式に街うといら条件をみたすことができた。

\section{$2 \cdot 2$ 試料金属}

’験に用いた武料金風の純度および調整法を次に䛉 す. 鉄は市收の再電解鉄（純度 $99.9 \%$ ）二ッケルは市販 のモンドニッケル $(99.9 \%)$ をそれぞれアルミナるつぼ に入れ高㓮波唀導加熱炉で浴融し，水素気流中で $2 \mathrm{~h}$ 脱 酸する，その後凝固試料を必要に必じた形状，重量に施 盤加にし， $900^{\circ} \mathrm{C} て ゙ 5 \mathrm{~h}$ 其空脱水素処理をした後用いた。 田一液混命による本法の妥当性を検璟するためのニッケ ル (液体)-鉄 (固体) 系の奏験の際には, 以上のように 処理した鉄を $1 \mathrm{~mm}$ の径に線引きして用いた。他の試料 は実験温度で固体で存在するため, 混合の際迅速に反応 が進さためには細線状が望李しいことを子備奏験で確認 した.クロムは線引きが困難なため市販の電解クロム $(99.2 \%)$ を幅 1〜2 mm, 厚さ $1 \mathrm{~mm}$, 長さ $20 \sim 30 \mathrm{~mm}$ の棒状に切断後, $1000^{\circ} \mathrm{C}$ で $2 \mathrm{~h}$ 真空脱ガスしたものを 用いた。同様にバナジウムは市販の釙状試料 $(99.8 \%)$ を用いた。その他の試料はそれぞれ市販の細線を表䤄研 磨し, 酸化皮膜を除去した後 $10 \sim 30 \mathrm{~mm}$ の長さに切断 したものを用いた。これらの金属の純度, 径は次のとお りである。

$$
\begin{aligned}
& \text { モリブデン: } 99.96 \% \text {, 径 } 0.3 \mathrm{~mm} \\
& \text { タングステン: } 99.95 \% \text {, 径 } 0.3 \mathrm{~mm} \\
& \text { ニオブおよびタンタル: } 99.5 \% \text {, 径 } 0.5 \mathrm{~mm}
\end{aligned}
$$

\section{$2 \cdot 3$ 実験操作}

混合前には常に下部谷器に固体試料が存在する以外, 実験操作は前報3）と全く同一である。但し両金属問の温
度着（最大 $1.5^{\circ} \mathrm{C}$ ) などに基つつく補川はト卜屾”行器に入 れた溶鉄同士の泚介による温度”変化を测运することによ り行つた.

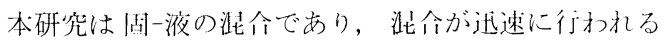
ことが留ましく，田怵试料の形状，装人状沉などをくら らした結果長くてもほぼ $1 \mathrm{~min}$ 以内に收大㴓度変化に達 しており，混价が比較的知时泪で行われているものと考

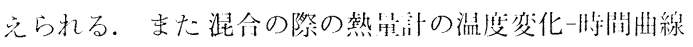

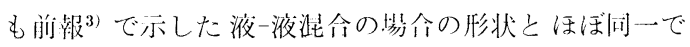

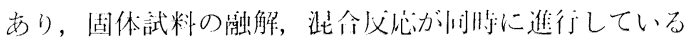
ものと考光られる。

\section{3. 実験結果および考察}

\section{$3 \cdot 1$ 測定原理および固-液混合法の検討}

混合した際に発生，あるいは吸收した熱星は，てれ に刘応する熱星叶本体の温度変化として測定，敦録され

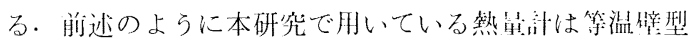
であり，熱星胡と等温壁との间の熱移動がこれらの間の 温度差に此例するといら。冷却に闵する Newton の近 似式に徒らことが確認されている。したがつて得られた

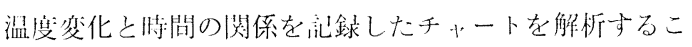
とにより（1）式を用いて熱星を算朋する。

$$
\lrcorner Q-(\lrcorner 0_{\mathrm{max}}+\right\lrcorner 0_{\mathrm{luss}}\right) W-\right\lrcorner q
$$

ここで

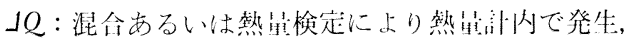
または吸収された熱星（cal）

$W:$ 熱量部の熱谷星 $\left(\mathrm{cal} /{ }^{\circ} \mathrm{C}\right)$

$J 0_{\text {max }}$ ：混含または熱昷検定によつて生じた熱早胡の 最大温度変化 $\left({ }^{\circ} \mathrm{C}\right)$

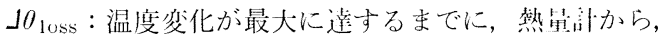
あるいは熱量副へ移動した熱晴による熱荲胡の 温度変化 (計算㑬) $\left({ }^{\circ} \mathrm{C}\right)$

\lrcorner $q$ : 溶媒金属, 溶質金属の温度涯による補正: 項 $(\mathrm{cal})$ 温度, 熱量変化の符号は熱星部より外部, すなわり等 温壁へ熱が移動する場命（発熱の場令）を鿇，熱が流入 する場合（吸熱の場合）を正と定義する。

なお本算出法については前城3) で詳細に述べている.

本研究で直接測定される熱星は (2) 式に小寸浴鉄と固 休金属 B 間の，固休 B を基準とする涅合熱 J $H^{\mathrm{R}}$ であ る.

$$
\left(1-X_{\mathrm{B}}\right) \mathrm{Fe}(1)+X_{\mathrm{B}} \mathrm{B}(\mathrm{s})=\mathrm{Fe}-\mathrm{B}(\mathrm{l})
$$

ただし $X_{\mathrm{B}}$ は企属 $\mathrm{B}$ の原子分率学亦与。

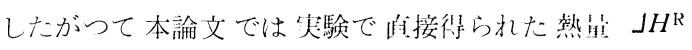

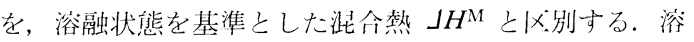
融鉄合金の混合熱 $J H^{\mathrm{M}}$ を求好には（3）式に示す金属 


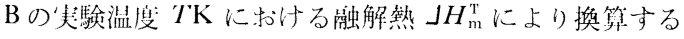
必要がある。

$$
\mathrm{B}(\mathrm{s})=\mathrm{B}(\mathrm{l})
$$

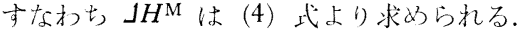

$$
\lrcorner H^{\mathrm{M}}-\right\lrcorner H^{\mathrm{R}}-X_{\mathrm{B}}\right\lrcorner H_{\mathrm{m}}^{\mathrm{m}}
$$

したがつて $J H_{\mathrm{m}}^{\mathrm{T}} を(5)$ 式により既知の金属 B の虽解 熱 $J H_{\mathrm{m}}$, 固体, 液体状態の比熱 $C_{\mathrm{p}}(\mathrm{s}), C_{\mathrm{p}}(1)$ の优を用 いて求めなけ狆ばならない。

$$
J H_{\mathrm{m}}^{\mathrm{T}}-J H_{\mathrm{m}}+\int_{\mathrm{m}, \mathrm{pt} .}^{T}\left\{C_{\mathrm{p}}(\mathrm{l}) \cdots C_{\mathrm{p}}(\mathrm{s})\right\} d T
$$

本研究に必要なこれら熱数佔は HULTGREN らの推奨値 ${ }^{4}$ より引用した。

本研究の国一液泚介による沘命熱測定法の可能性と妥 当性を確諗するために，浴鉄一向融点金属系の測定に先 立たっニッケルー鉄系の测定を行つた. $1500^{\circ} \mathrm{C} の$ 尖騟温 度で鉄は固体，二ッケルは液休であり，液一液の混全决 験についても $1600^{\circ} \mathrm{C}$ で行罻に行え，さらにすでに著者

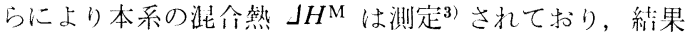
の比較が可能である. 澌定絬果を Fig. 2 に示す。換算 に用いた鉄の $1500^{\circ} \mathrm{C} に$ 打ける $J H_{117}^{1773}$ は $3265 \mathrm{cal}$

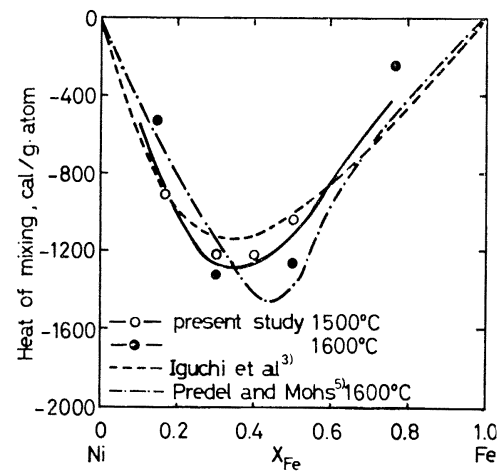

Fig. 2. Heat of mixing of nickel-iron alloys. $\mathrm{g} \cdot \mathrm{atom}^{4)}$ である。困から闹-液沚命で求め液体基準に換 算した值と，液一液混命で目接求めた值とは垁験吅差籁 閅内で一致しており，洁合熱の温度依存性が少ないとい らことを考揌し，固一液混合により混合熱を求める力法 が液一液状態で混合熱を測定できない系についても有効 であると考えられる。

\section{$3 \cdot 2$ 溶融鉄-クロム 2 元合金の混合熱}

$X_{\mathrm{C}_{\mathrm{r}}}=0 \sim 0.31$ の組成範田に括忛る混合熱を $1590^{\circ} \pm$ $10^{\circ} \mathrm{C}$ の温度で測定し, 結果を Table 1 と Fig. 3 に示 す。液一液混命の埸命は発熱反忘である. 換算に用いた $J H_{\mathrm{m}}^{1863}$ の值は $4610 \mathrm{cal} / \mathrm{g} \cdot \mathrm{atom}^{4)}$ である. クロム試料に ついては細線状のものが得られなかつたため，混食が先 全に終厂するのに $1 \mathrm{~min}$ 以上要した場合がある。本系の 汪命熱を固接求わた研究は従米全く見あたらないが，溶

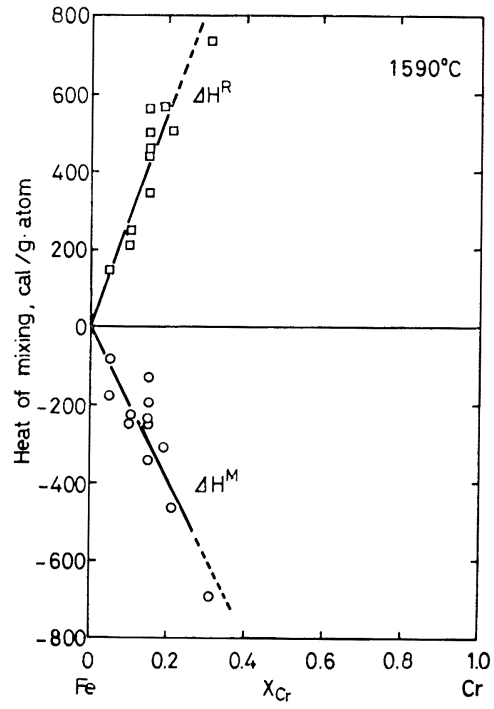

\begin{tabular}{|c|c|c|c|c|c|c|c|c|}
\hline Heat No. & Sample wt. & Composition & $t_{\operatorname{mix}}$ & \lrcorner$\theta_{\max }$ & $J \theta_{\text {loss }}$ & Heat capacity of & \multicolumn{2}{|c|}{$\begin{array}{c}\text { Heat of mixing } \\
\mathrm{cal} / \mathrm{g} \cdot \mathrm{atom}\end{array}$} \\
\hline & & $\begin{array}{l}\text { at. Iraction } \\
X_{\mathrm{Cr}}\end{array}$ & $\mathrm{s}$ & & & $\begin{array}{l}\text { the calorimeter } \\
\qquad W, \text { cal } /{ }^{\circ} \mathrm{C}\end{array}$ & $J H^{\mathrm{R}}$ & $J H^{\mathrm{M}}$ \\
\hline $\mathrm{FF} \cdots 1$ & $\begin{array}{l}\text { Solute Fe } \\
0.673\end{array}$ & $\mathrm{Fe}-\mathrm{Fe}$ & 23 & 1.11 & 0.10 & 31.1 & $\begin{array}{r}55.9 \mathrm{cal} / \mathrm{g} . \\
\text { sol }\end{array}$ & $\mathrm{Fe}$ \\
\hline FCir 3 & 1.001 & 0.05 & 51 & 2.04 & 0.29 & 44.6 & 50 & -180 \\
\hline $\mathrm{FCr} 4$ & 0.891 & 0.15 & 74 & 8.28 & 1.88 & 34.8 & 350 & -340 \\
\hline $\mathrm{FCr} 6$ & $1.0+4$ & 0.19 & 106 & 7.08 & 1.94 & 71.1 & 570 & -310 \\
\hline $\mathrm{FCr}-7$ & 1.099 & 0.10 & 70 & 7.16 & 1.71 & $32 .+$ & 210 & -250 \\
\hline $\mathrm{lar} 13$ & 0.883 & 0.0 .5 & 16 & 5.12 & $0 .+1$ & 31.9 & 1.50 & -80 \\
\hline I:Cr 15 & 1.007 & 0.31 & 88 & 20.58 & 3.35 & 32.6 & 740 & .690 \\
\hline $\mathrm{FCor} 16$ & 0.972 & $0.10 t$ & 68 & 7.44 & 1.91 & 31.4 & 250 & -230 \\
\hline $\mathrm{F} C \mathrm{Cr} 20$ & 0.815 & 0.15 & 41 & 13.03 & 3.82 & 29.5 & 560 & -130 \\
\hline $\mathrm{FCr}-22$ & 0.855 & 0.15 & 50 & 11.93 & 3.02 & 27.8 & 440 & -250 \\
\hline $\mathrm{FCr}-23$ & 0.837 & 0.15 & 53 & 9.40 & 2.31 & 36.2 & 460 & -230 \\
\hline FCr- 25 & 0.835 & 0.21 & 68 & 5.07 & 0.80 & 78.2 & 510 & -460 \\
\hline
\end{tabular}

Fig. 3. Heat of mixing of iron-chromium alloys.

Table 1. Experimental data of liquid iron-chromium alloys $\left(1590^{\circ} \pm 10^{\circ} \mathrm{C}\right)$. 
触鉄-ク口ム合金中のクロムの活旨は赺電力測定 ${ }^{6)}$, 蒸父

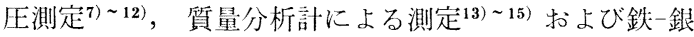
間の分配平衡測定 ${ }^{16)}$ により求められている. しかしなが らそれらの測定值のばらつきは非常に大きく一致してい ない. RAO ら ${ }^{17)}$ は FRUeHAN ${ }^{6)}$ の活量測定值より $\alpha$ 関 数を線形回㷌法により濃度と温度の阅数として求め, 混 合熱を胡算している。 それによれば $X_{\mathrm{Cr}}=0.65$ の組成 で最大值 $J H^{\mathrm{M}}=800 \mathrm{cal} / \mathrm{g} \cdot$ atom を垫めている. また KUBASCHEWSKI $5^{18)}$ は Knudsen cell 流出法を用い, 蒸 父王測定により固体鉄ークロム合金のクロムの活量を求 め，正則溶液であると仮定し，液体についても混合熱を 推測し, その值は吸熱で最大值は $X_{\mathrm{Cr}}=0.35$ で $220 \mathrm{cal} /$ g.atom であるとしている. さらに最近 KUBASCHEwsKI

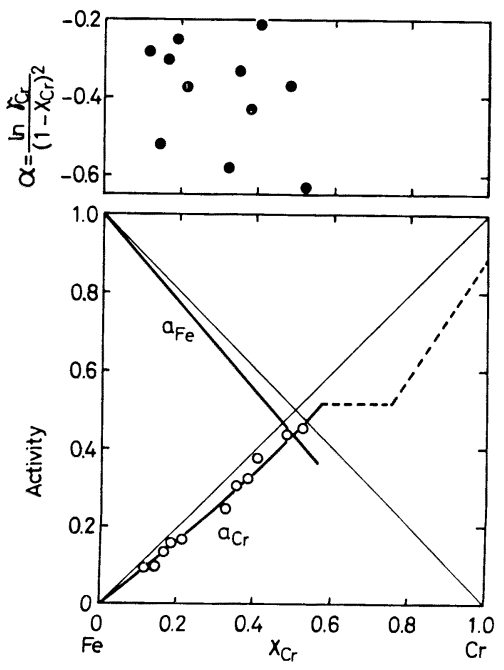

Fig. 4. Activity of chromium and $\alpha$ function in $\mathrm{Fe}-\mathrm{Cr}$ alloys at $1600^{\circ} \mathrm{G}$ by $R . J$. Fruenan ${ }^{6}$. (Liquid $\mathrm{Cr}$ reference, $\alpha$ function calculated by authors).
ら 19) は $X_{\mathrm{Cr}}=0.5$ で $1245 \mathrm{cal} / \mathrm{g} \cdot$ atom という高い佔を 推奨している、いずれも本研究結果と異なり, 吸熱とい ら正反対の傾向を示している。 しかしながら，Fig. 4 に示寸よらに，著者らが FRUEHAN ${ }^{6)}$ の活量佔より $\alpha$ 阙数を求めると, ばらつきは大きいがほぼ組成に依存し ていない，彼の活量の但は们に俩偷しており，したがつ て正則溶液として取り扱えば份の混全熱を示すはずであ り，前述の RAO ら ${ }^{17)}$ の取り扱いには疑問がある。また ELLIOTT ら 20$)$ は理想溶液と仪定して取り敃つている.

HultgRen ら ${ }^{21}$ は蒸気压测定による ONILlON と OleT$\mathrm{TE}^{7)}$ の活量測定优および FRUEHAN ${ }^{6)}$ の起電力測定結果 とを組又合わせ，熱力学的諸星を推将している。それに よれば，鉄およびクロムの活星ともわずかではあるが负

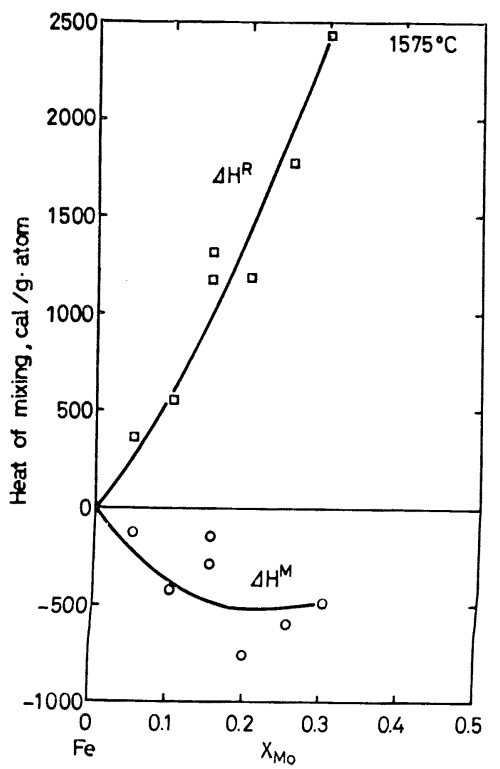

Fig. 5. Heat of mixing of iron-molybdeum alloys.

Table 2. Experimental data of liquid iron-molybdenum alloys $\left(1575^{\circ} \pm 15^{\circ} \mathrm{C}\right)$.

\begin{tabular}{|c|c|c|c|c|c|c|c|c|}
\hline \multirow[t]{2}{*}{ Heat No. } & \multirow{2}{*}{$\begin{array}{l}\text { Sample wt. } \\
\mathrm{g} \cdot \text { atom }\end{array}$} & \multirow{2}{*}{$\begin{array}{l}\text { Composition } \\
\text { at. fraction } \\
X_{M_{0}}\end{array}$} & \multirow{2}{*}{$t_{\mathrm{mix}}$} & \multirow{2}{*}{$\stackrel{J \theta_{\max }}{{ }^{\circ} \mathrm{C}}$} & \multirow{2}{*}{$\begin{array}{l}J \theta_{100 s} \\
{ }^{\circ} \mathrm{C}\end{array}$} & \multirow{2}{*}{$\begin{array}{l}\text { Heat capacity of } \\
\text { the calorimeter } \\
\quad W \text {, cal } /{ }^{\circ} \mathrm{C}\end{array}$} & \multicolumn{2}{|c|}{$\begin{array}{c}\text { Heat of mixing } \\
\text { cal/g.atom }\end{array}$} \\
\hline & & & & & & & $J H^{\mathrm{R}}$ & $J H^{\mathrm{M}}$ \\
\hline $\mathrm{l} F-2$ & $\begin{array}{l}\text { Solute Fe } \\
0.520\end{array}$ & $\mathrm{Fe}-\mathrm{Fe}$ & 15 & -1.90 & -0.13 & 54.8 & \multirow{2}{*}{\multicolumn{2}{|c|}{$\begin{array}{c}-213 \mathrm{cal} / \mathrm{g} \cdot \text { atom of } \\
\text { solute } \mathrm{Fe} \\
-201 \mathrm{cal} / \mathrm{g} \cdot \text { atom of } \\
\text { solute fe }\end{array}$}} \\
\hline $\mathrm{FF}-3$ & $\begin{array}{l}\text { Solute Fe } \\
0.518\end{array}$ & $\mathrm{IeC}$ & 8 & -2.10 & -0.06 & 48.3 & & \\
\hline IMo I & 0.581 & 0.10 & 17 & 7.58 & 0.68 & 25.7 & 550 & -420 \\
\hline IMO.2 & 0.649 & 0.20 & 30 & 11.96 & 1.63 & 48.7 & 1200 & $\cdots 7(6)$ \\
\hline FMo 3 & $0.5+2$ & 0.0 .5 & 18 & 1.72 & 0.13 & 48.1 & 360 & -130 \\
\hline$F M_{0} 4$ & $0.7+0$ & 0.30 & 30 & 36.60 & 3.35 & 42.4 & 2400 & $-+9(1)$ \\
\hline FMo 5 & 0.603 & 0.15 & 19 & 17.65 & 1.49 & 36.0 & 1300 & -140 \\
\hline FMo 6 & 0.694 & 0.254 & 20 & 26.83 & 2.37 & 38.5 & 1800 & -600 \\
\hline $\mathrm{FF}-4$ & $\begin{array}{c}\text { Solute Fe } \\
0.673\end{array}$ & $\mathrm{Fe} \mathrm{le}$ & 30 & -0.95 & -0.03 & 45.3 & \multicolumn{2}{|c|}{$\begin{array}{c}-66 \mathrm{cal} / \mathrm{g} \cdot \mathrm{atom} \text { of } \\
\text { solute } \mathrm{Fe}\end{array}$} \\
\hline FMo-7 & 0.775 & 0.15 & 15 & 18.96 & 2.21 & 40.9 & 1200 & -290 \\
\hline
\end{tabular}


に偏倚している。 また最近の丸山，萬谷 ${ }^{12)} の$ 蒸気圧測定 による活量の值も顛に偏拊している.

本系に関してはその車要性から多くの研究がなされて いるにもかかわらず，いまだ純ク口ムの融点および融解 熱, そのものにも大きなばらつきがあり, 令後さらに検 剖すべき系であると考えられる。

\section{3 溶融鉄-モリブデン 2 元合金の混合熱}

$1575^{\circ} \pm 15^{\circ} \mathrm{C}$ の㴓度で， $X_{\mathrm{M} 0}=0 \sim 0.30$ の組成範用に おける混全熱 $J H^{\mathrm{R}}$ を測定した。 その結果を Table 2 と Fig. 5 に亦守。得られた倠は組成に刘し明瞭な依存性 が垫められる。一方，液体基準の混介熱 $J H^{\mathrm{M}}$ は非常に 价らつきが大きいが，わずかな発熱を示す倾们が新めら れる。換算に䏳いた $\Delta H_{\mathrm{m}}^{1848}$ の佔は $9730 \mathrm{cal} / \mathrm{g} \cdot \mathrm{atom}$ で

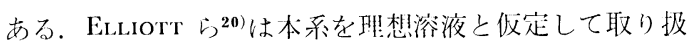

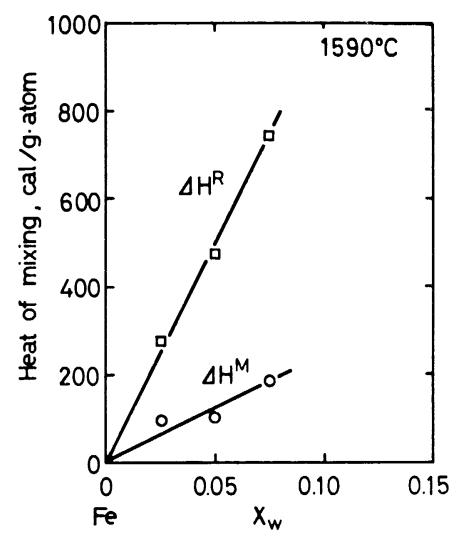

Fig. 6. Heat of mixing of iron-tungsten alloys.
つている.

\section{4 溶融鉄-タングステン 2 元合金の混合熱}

温度 $1590^{\circ} \pm 18^{\circ} \mathrm{C}$ で $X_{\mathrm{W}}=0 \sim 0.075$ のごく狭い組 成籁用における注命熱 $A H^{\mathrm{R}}$ を測定した。 その絬果を Table 3 と Fig. 6 に示す。四から液体基準の混命熱 $J H^{\mathrm{M}}$ は吸熱を示すことが垫められる。換算に用いた $J H_{\mathrm{m}}^{18633}$ の㑑は $7440 \mathrm{cal} / \mathrm{g} \cdot \mathrm{atom}^{4)}$ である。本系に関して も先の鉄-モリブデン 2 元系と同様，混命熱その他の熱

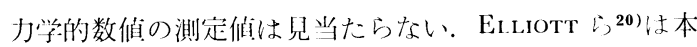

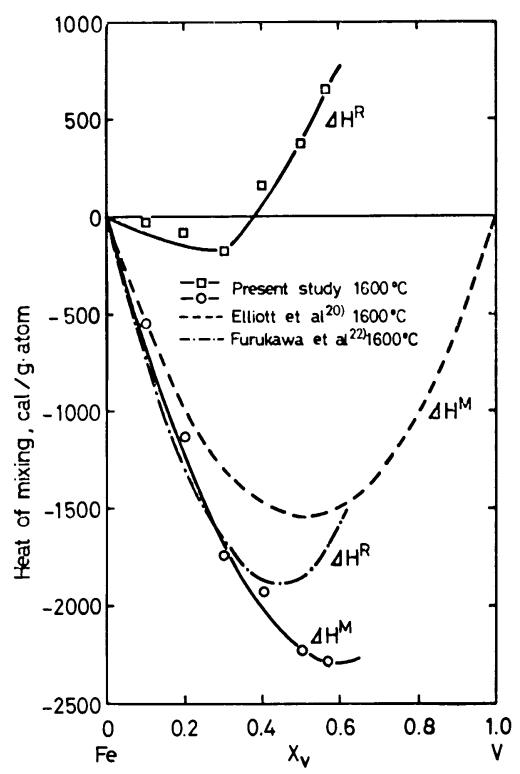

Fig. 7. Heat of mixing of iron-vanadium alloys.

Table 3. Experimental data of liquid iron-tungsten alloys $\left(1590 \pm 18^{\circ} \mathrm{C}\right)$.

\begin{tabular}{|c|c|c|c|c|c|c|c|c|}
\hline \multirow{2}{*}{ Heat No. } & \multirow{2}{*}{$\begin{array}{l}\text { Sample: wt. } \\
\mathrm{g} \cdot \mathrm{atom}\end{array}$} & \multirow{2}{*}{$\begin{array}{l}\text { Composition } \\
\text { at. fraction } \\
X_{W}\end{array}$} & \multirow{2}{*}{$t_{\mathrm{six}}$} & \multirow{2}{*}{$J \theta_{\max }$} & \multirow{2}{*}{$\begin{array}{c}\Delta \theta_{1 \mathrm{sss}} \\
{ }_{\circ}^{\circ}:\end{array}$} & \multirow{2}{*}{$\begin{array}{c}\text { Heat capacity of } \\
\text { the calorimeter } \\
W \text {, cal } /{ }^{\circ} \mathrm{C}\end{array}$} & \multicolumn{2}{|c|}{$\begin{array}{c}\text { Heat of mixing } \\
\text { cal/g.atom }\end{array}$} \\
\hline & & & & & & & $\Delta H^{\mathrm{R}}$ & $J H^{\mathrm{M}}$ \\
\hline $\mathrm{FF}-5$ & $\begin{array}{c}\text { Solute Fe } \\
0.494\end{array}$ & $\mathrm{Fe} \mathrm{Fe}$ & 15 & -1.52 & -0.06 & 48.7 & $\begin{array}{r}-156 \mathrm{cal} / \mathrm{g} \\
\mathrm{so}\end{array}$ & Fe \\
\hline $\mathrm{I} W \mathrm{~W}-3$ & 0.552 & 0.05 & 23 & 4.08 & 0.44 & 39.9 & 470 & 100 \\
\hline FW 6 & 0.535 & 0.025 & 14 & 1.69 & 0.07 & 38.6 & 280 & 90 \\
\hline FW 7 & 0.540 & 0.075 & 28 & 7.88 & 1.14 & 36.0 & 750 & 190 \\
\hline
\end{tabular}

Table 4. Experimental data of liquid iron-vanadium alloys $\left(1600^{\circ} \mathrm{C} \pm 10^{\circ} \mathrm{C}\right)$.

\begin{tabular}{|c|c|c|c|c|c|c|c|c|}
\hline \multirow{2}{*}{ Heat No. } & \multirow{2}{*}{$\begin{array}{c}\text { Sample wt. } \\
\text { g.atom }\end{array}$} & \multirow{2}{*}{$\begin{array}{l}\text { Composition } \\
\text { at. fraction } \\
X_{V}\end{array}$} & \multirow{2}{*}{$\underset{\mathrm{s}}{t_{\mathrm{mix}}}$} & \multirow{2}{*}{$\stackrel{J}{J} \theta_{\max }$} & \multirow{2}{*}{$\begin{array}{l}\Delta \theta_{10 \mathrm{ss}} \\
{ }^{\circ} \mathrm{C}:\end{array}$} & \multirow{2}{*}{$\begin{array}{l}\text { Heat capacity of } \\
\text { the calorimeter } \\
W \text {, cal/ }{ }^{\circ} \mathrm{C}\end{array}$} & \multicolumn{2}{|c|}{$\begin{array}{c}\text { Heat of mixing } \\
\text { cal } / g \cdot \text { atom }\end{array}$} \\
\hline & & & & & & & $\Delta H^{\mathrm{R}}$ & $J H^{\mathrm{M}}$ \\
\hline $\mathrm{FF} 6$ & $\begin{array}{l}\text { Solute } \mathrm{Fe} \\
\quad 0.446\end{array}$ & $\mathrm{Fe} \mathrm{Fe}$ & 23 & -0.79 & -0.30 & 37.8 & $-92.5 \mathrm{cal}$ & $\begin{array}{l}\mathrm{g} \cdot \mathrm{atom} \text { of } \\
\text { solute } \mathrm{Fe}\end{array}$ \\
\hline$V 1$ & 1.1 .77 & 0.20 & 10 & -4.89 & -0.21 & 37.5 & -90 & -1100 \\
\hline FV -3 & 0.954 & 0.30 & 11 & -6.62 & -0.34 & 33.7 & -180 & -1700 \\
\hline $\mathrm{FV}-4$ & 0.613 & 0.50 & 41 & 5.72 & 1.22 & 28.4 & 370 & -2200 \\
\hline $1 \mathrm{~V} 14$ & 0.862 & 0.40 & 60 & 1.90 & 0.55 & 35.0 & 160 & -1900 \\
\hline FV 15 & 1.328 & 0.10 & 31 & -3.45 & $\ldots 0.79$ & 35.4 & -30 & -550 \\
\hline $\mathrm{FV} 16$ & 0.622 & 0.56 & 35 & 7.52 & 3.68 & 33.7 & 6.50 & -2300 \\
\hline
\end{tabular}


Table 5. Experimental data of liquid iron-niobium alloys $\left(1600^{\circ} \pm 13^{\circ} \mathrm{C}\right)$.

\begin{tabular}{|c|c|c|c|c|c|c|c|c|}
\hline \multirow[t]{2}{*}{ Heat No. } & \multirow{2}{*}{$\begin{array}{c}\text { Sample wt. } \\
\text { g.atom }\end{array}$} & \multirow{2}{*}{$\begin{array}{c}\text { Composition } \\
\text { at. fraction } \\
X_{\mathrm{Nb}}\end{array}$} & \multirow{2}{*}{$t_{\mathrm{mix}}$} & \multirow{2}{*}{$\underset{\circ}{J} f_{\max }$} & \multirow{2}{*}{$\stackrel{j \theta_{10 \mathrm{ss}}}{{ }^{\circ} \mathrm{C}}$} & \multirow{2}{*}{$\begin{array}{c}\text { Heat capacity of } \\
\text { the calorimeter } \\
W, \text { cal } /{ }^{\circ} \mathrm{C}\end{array}$} & \multicolumn{2}{|c|}{$\begin{array}{c}\text { Heat of mixing } \\
\mathrm{cal} / \mathrm{g} \cdot \text { atom }\end{array}$} \\
\hline & & & & & & & $J H^{\mathrm{R}}$ & $J H^{\mathrm{M}}$ \\
\hline FF-7 & $\begin{array}{c}\text { Solute Fe } \\
0.516\end{array}$ & $\mathrm{Fe}-\mathrm{Fe}$ & 12 & -0.52 & -0.04 & 36.3 & -39.4 & $\begin{array}{l}\mathrm{g} \cdot \text { atom of } \\
\text { solute Fe }\end{array}$ \\
\hline FNb-1 & 1.046 & 0.10 & 14 & -7.37 & -1.36 & 28.3 & -200 & -830 \\
\hline FNb-2 & 0.856 & 0.20 & 33 & -9.49 & -1.02 & 40.0 & -460 & --1700 \\
\hline FNb-3 & 1.005 & 0.05 & 13 & -6.34 & -0.38 & 33.6 & -190 & -500 \\
\hline $\mathrm{FNb} 4$ & 1.044 & 0.15 & 30 & -8.92 & -1.19 & 36.7 & -320 & -1300 \\
\hline $\mathrm{FNb} 5$ & 0.719 & 0.25 & 51 & -11.28 & -1.60 & 43.6 & -750 & -2300 \\
\hline
\end{tabular}

Table 6. Experimental data of liquid iron-tantalum alloys $\left(1593^{\circ} \pm 6^{\circ} \mathrm{C}\right)$.

\begin{tabular}{|c|c|c|c|c|c|c|c|c|}
\hline \multirow[t]{2}{*}{ Heat No. } & \multirow{2}{*}{$\begin{array}{c}\text { Sample wt. } \\
\mathrm{g} \cdot \mathrm{atom}\end{array}$} & \multirow{2}{*}{$\begin{array}{c}\text { Composition } \\
\text { at. fraction } \\
X_{\mathrm{T} i}\end{array}$} & \multirow{2}{*}{$t_{\mathrm{mix}}$} & \multirow{2}{*}{$\underset{C:}{J \theta_{11}}$} & \multirow{2}{*}{$\underset{{ }^{\circ}(:)}{j \theta_{10 s s}}$} & \multirow{2}{*}{$\begin{array}{c}\text { Heat capacity of } \\
\text { the calorimeter } \\
W \text {, cal/ }{ }^{\circ} \mathrm{C} \text { : }\end{array}$} & \multicolumn{2}{|c|}{$\begin{array}{l}\text { Heat of mixing } \\
\text { cal/g.atom }\end{array}$} \\
\hline & & & & & & & $J H^{R}$ & $J H^{\mathrm{M}}$ \\
\hline FF -8 & $\begin{array}{l}\text { Solute } \mathrm{Fe} \\
\quad 0.690\end{array}$ & $\mathrm{Fe}-\mathrm{I} \mathrm{C}$ & 14 & -0.96 & -0.06 & 30.4 & -44.9 cal & $\begin{array}{l}\text { atom of } \\
\text { olute } \mathrm{Fe}^{\text {e }}\end{array}$ \\
\hline FTa 1 & 1.018 & 0.025 & 40 & -2.01 & -0.16 & 63.0 & -90 & -230 \\
\hline $\mathrm{FTa} 2$ & 1.024 & 0.049 & 32 & -7.26 & -1.24 & 35.4 & -250 & -530 \\
\hline FIa 3 & 1.070 & 0.073 & 45 & -9.12 & -1.70 & 32.7 & -290 & -710 \\
\hline FTa 5 & 1.093 & 0.10 & 40 & -11.40 & -1.59 & 37.7 & -410 & .980 \\
\hline Fla 6 & 1.120 & $0.11 . t$ & 50 & -12.20 & -2.03 & 41.0 & $\ldots 480$ & $\ldots 1100$ \\
\hline FTa 8 & 1.096 & 0.15 & 41 & -15.00 & -2.38 & 33.8 & -500 & $-1+00$ \\
\hline
\end{tabular}

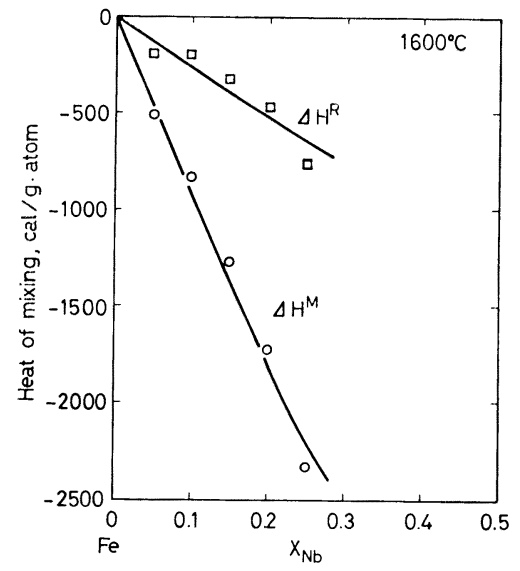

Fig. 8. Heat of mixing of iron-niobium alloys.

系についても理想溶液老仪等している。

\section{5 溶融鉄ーバナジゥム 2 元合金の混合熱}

$1600^{\circ} \pm 10^{\circ} \mathrm{C}$ における混命熱 $J H^{\mathrm{R}}$ を $X_{\mathrm{V}}=0 \sim 0.56$ の組成範明において測定した。 その結果を Table 4,

Fig. 7 に示す.換算に用いた $J H_{\mathrm{m}}^{1873}$ は $5210 \mathrm{cal} / \mathrm{g} \cdot \mathrm{atom}^{4)}$ である、Chipman, Dastur ${ }^{22)}$ は無限稀薄におけるバナ ジウムの活量係数を ${ }^{\circ}>0.12$ と推测しておうり, ElLIOTT $5^{20)}$ は ChIPMAN ${ }^{23)}$ の活荲測定值より，この系を正則溶 液と仮定し混合熱を計算している・FUREHAN ${ }^{24)}$ は固体 電解質を用いた起電力測定により，Fe-V-O 系のバナジ ウムの活量を原子分率 $X_{\mathrm{V}}<0.4$ の組成籁网について求 め，大きく負に作偷していることを跟隹している。また

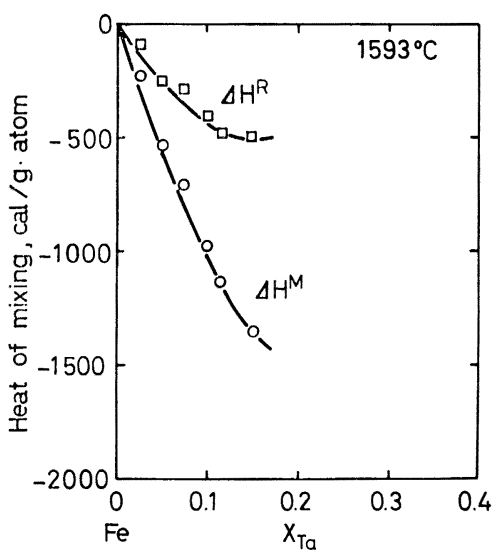

Fig. 9. Heat of mixing of iron-tantalum alloys.

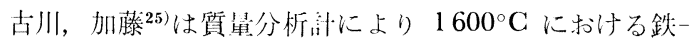
バナジウム系のバナジウム国体基準の混介熱 $J H^{\mathrm{R}}$ を求 めている・これらの結果を本研究絬果と比較のため Fig. 7 に示す。本研究結果と ELLIOTT ら ${ }^{20)}$ の結果とは倾问は 非常によく一致しているが，占川ら25)の絬果は大きく其 なつている。無限稀薄溶液でのバナジウムの部分モル混 今熱は $-5800 \mathrm{cal} / \mathrm{g} \cdot$ atom であり, ElLLIOTT らは -6350 $\mathrm{cal} / \mathrm{g} \cdot$ atom の俻を報售している.

\section{6 溶融鉄-ニオブ 2 元合金の混合熱}

$1600^{\circ} \pm 13^{\circ} \mathrm{C}$ における混命熱 $J H^{\mathrm{R}}$ を $X_{\mathrm{Nb}}=0 \sim 0.25$ の組成籁用において測定した。 その結果を Table 5, Fig. 8 に示す。換算に用いた $J H_{\mathrm{m}}^{1873}$ の佔は $6320 \mathrm{cal} /$ $\mathrm{g} \cdot \mathrm{atom}^{4)}$ である。本系の $J H^{\mathrm{R}}$ は発熱を小し，ての絬果 
液体基準の混命熱 $J H^{\mathrm{M}}$ は大きな负の值となる。本系に

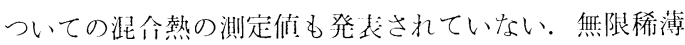
溶液での二オブの部分モル混介熱として J $H_{\mathrm{N}}^{\mathrm{M}}=-9400$ $\mathrm{cal} / \mathrm{g} \cdot \mathrm{atom}$ を得た。

\section{7 溶融鉄-タンタル 2 元合金の混合熱}

$1593^{\circ} \pm 6^{\circ} \mathrm{C}$ における混命熱 $4 H^{\mathrm{R}}$ を $X_{\mathrm{Ta}}=0 \sim 0.15$ の糺成䉓用で测定した，その絬果を Table 6, Fig. 9 に 示寸。換算に用いた $J H_{\mathrm{m}}^{1866}$ の佔は $5700 \mathrm{cal} / \mathrm{g} \cdot \mathrm{at}^{3} \mathrm{~m}^{4)}$ で ある. 本系の沘介熱の澌定做についても従米報㸃されて いない，無限稀沙溶液でのタンタルの部分モル混全熱は - $11000 \mathrm{cal} / \mathrm{g} \cdot$ atom である.

\section{8 測定精度および本測定法の妥当性}

$\mathrm{Va}$ 族，VIa 族の元素バナジウム，ニオブ，タンタル， クロム，モリブデン，タングステンなどは鋼の介銀元素

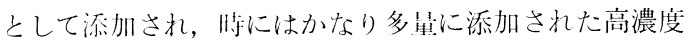
の介鋼も用いられ，鋼の性:質を问上させている.しか しながらこれらの菜は高融点を有し，比較们酸化しや 寸い元素も多く, ’駼が洲難なことから基本的な 2 元系 に関する研究は兵しい。そこで本研究は，先に著者らが

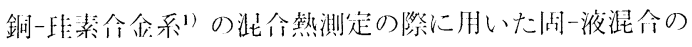

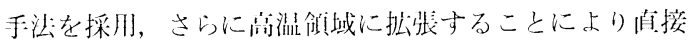
測定倠を得ることを成みたものである。

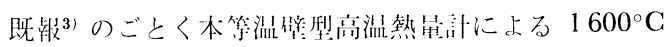

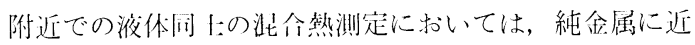
い熱放毠るいは吸收が少ない組成においても，その測

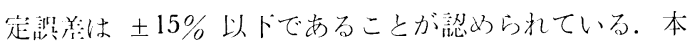
研究において液一液涯合と型なる点は次の 2 点である。

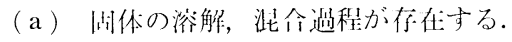

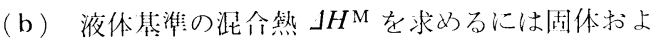
び液体の比熱，融点，融解熱など他の熱化学数佔を用い た換算が必琶である。

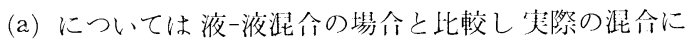
要する特間は長い.しかしながらいずれの系においても Newton の冷却の法則を満足していることが確認され た。また笑験終了後の試料断们を数っ所 EPMA で分析 したところ，凝固に伴らと考えられるミクロ偏析は認め られたものの, 浴解不卜分に起肉するようなマクロ㣂析 は涩められず，淐价により均一な溶液が形成されたこと を裏つけている.さらに溶解, 混命を促進するため, 細 線などを用いており衣伯䅡が非常に大きい。したがつて もし混命前にごく微荲でも永㑑が酸化した場命は䛊差を 生ずる原因となる。これらの䛊差は定量化することが非 常に困難であるが，刘策としては零用気であるアルゴン の精製を十分に行らことにより，それに伴ら呪着を最小 にするよらに努めた。
以上固-液混合によつて得られた実測值である混合熱 $J H^{\mathrm{R}}$ の铞养は既報の液一液混介の場介と同様 $\pm 15 \%$ 以 下であると若えられる。

一方 (b ) における熱化学数值については央測值がな く，推測佔であつたり，また奏測值であつても5000 $\mathrm{cal} / \mathrm{g} \cdot \operatorname{atom}$ に対し $\pm 800 \mathrm{cal}$ 程度の精度の值が多く,こ の換算が液体基淮の混会熱の精度を大きく落有する。 なわりニッケルー鉄系のごとく，融点近傍の鉄の熱化学: 数值の精度が高い場命には固一液混命熱を換算した液体

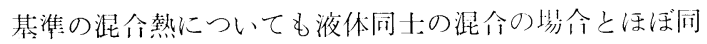
程度の精度を期待できる。

以上本研究により既㣮と闹程度の精度で姑一液混合熱 JH $\mathrm{R}$ が求められた。したがつて, 尖際の金属製鍊分野 および治金物理化学の基楚的分野においても, 溶融状態 で測定が材難な系について有用な任を得る一手段として 本法は份扮であると考光られる。

\section{4. 結言}

（1） $1500^{\circ} \mathrm{C}$ において溶融二ッケルー固体鉄の涅命

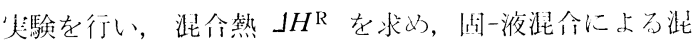
介熱測定の妥当性を確涊した。

(2) $1600^{\circ} \mathrm{C}$ に拉いて鉄-クロム，鉄-モリブデン， 鉄ータングステン，鉄-バナジウム，鉄-ニオブ，鉄ータン

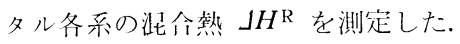

（3）得られた[国]液泥会熱から熱化学数值を用いて 換算することにより液体基準の混介熱 $J H^{\mathrm{M}}$ を求めた.

終わりに，本研究遂行に当たり，御協力いただいた， 富阙正喜, 飯由裕伸, 两丁学士および東北大学「学部众 属下:学科助手，们牛不二夫，日野光儿雨厂：学博士に感谢 致します。ならびに終始御助、御指尊を唄りました東 北大学「学部食属厂学科, 萬行志郎教授に深く感谢致し ます。

\section{文献}

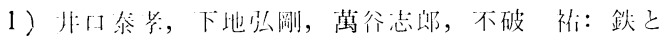
鋼，63 (1977)，p. 275

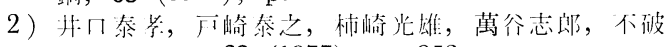
祚：鉄と鋼，63(1977)，p. 953

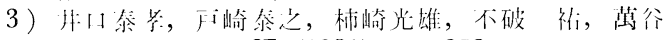
志即：鉄と銓，67 (1981)，p. 952

4 ) R. Hultgren, $P . D$. Desai, D. T. Hawkins, $M$. Gleiser, and $K . K$. Kelley: Selected Values of the Thermodynamic Properties of the Elements (1973) [ASM]

5 ) B. Predel and $R$. Mohs: Arch. Eisenhüttenw., 41 (1970), p. 143

$6)$ R. J. Fruehan: Trans. Met. Soc. AIME, 245 (1969), p. 1215

7 ) M. Onillon and M. Olette: Compt. Rend., Ser. C, 264 (1967), p. 46 
$8)$ I. A. Pavars, B. A. Baum, and $P . V$. Gel'd: High Temp., 8 (1970), p. 67

9 ) $A . P$. Lyubimov and $A \cdot A$. Granovskaya: Sb. Moscow Inst. Stali, 34 (1955), p. 95

10) $H$. Wada, Y. Kawai, and T. Saito: Sci. Rept. Res. Inst. Tohoku Univ., 13 (1961), p. 96

11) K. C. Mills and P. Grieveson: J. Chem. Thermodynamics, 8 (1976), p. 545

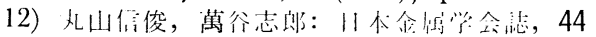
(1980), p. 1422

13) S. W. Gilby and G. R. St. Pierre: Trans. Met. Soc. AIME, 245 (1969), p. 1749

14) R. B. Reese, R. A. RAPP, and G. R. St. Pierre: Trans. Met. Soc. AIME, 242 (1968), p. 1719

15) $G . R$. Belton and $R . J$. Fruehan: Met. Trans., $1(1970)$, p. 781

16) $H . G$. Hadrys, M. G. Frohberg, and $J . F$. ElliotT: Met. Trans., 1 (1970), p. 1867

17) $M . V . \mathrm{R}_{\mathrm{AO}}$ and $W . A$. Tillek: Mat. Sci. Eng., 14 (1974), p. 47
18) $O$. Kubaschewski and $G$. Heymer: Acta Met., 8 (1960), p. 416

19) $O$. Kubaschewski and $C$. B. Alcock: Metallurgical Thermochemistry, 5th Edition (1979) [Pergamon Press]

20) $J . F$. Elliott, $M$. Gleiser, and $V$. RamaKRISHNA : Thermochemistry for Steelmaking II, (19ô3) [Addison Wesley]

21) $R$. Hultgren, $P$. D. Desai, $D . T$. Hawkins, $M$. Gleiser, and $K$. K. Kellffy: Selected Values of the Thermodynamic Properties of Binary Alloys (1973) |ASM |

22) J. Chipman and $M . N$. Dastuk: J. Metals, 191 (1951), p. 111

23) J. Chipman : International Conference on Pure and $\Lambda$ pplied Chemistry, IUPAC, Montreal (1961)

24) R. J. Fruehan: Met. Trans., 1 (1970), p. 2083

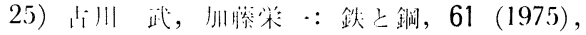
p. 3050 